Зубілевич С. Я., к.е.н., професор (Національний університет водного господарства та природокористування, м. Рівне)

\title{
ФОРМУВАННЯ ТА РОЗКРИТТЯ ОБЛІКОВОЇ ПОЛІТИКИ ЗА МСФЗ 15 «ДОХІД ВІД ДОГОВОРІВ 3 КЛІЄНТАМИ»
}

Визначено основні елементи облікової політики стосовно доходу, до яких віднесено основу ведення обліку і подання звітності, суттєвість, згортання, робочий план рахунків, об'єкт обліку, визначення, визнання, класифікацію, оцінку, розкриття та інші. Запропоновано розрізняти такі складові облікової політики: для потреб складання регламенту з облікової політики та приміток до фінансових звітів; загальні та такі, які безпосередньо стосуються окремого елемента фінансової звітності; постійні та тимчасові, призначені для переходу на нові (переглянуті) стандарти. Проведено порівняння вимог МСБО 18 «Дохід», МСБО 11 «Будівельні контракти» та МСФЗ 15 «Дохід від договорів з клієнтами» щодо термінології і переліку основних елементів облікової політики та оцінки. Запропонований підхід до формування наказу про облікову політику в частині доходу 3 урахуванням вимог МСФЗ 15 . Проведений аналіз фінансових звітів підприємств щодо визнання, оцінки та розкриття доходу у проміжній фінансовій звітності за 2018 рік відповідно до вимог МСФЗ 15. Узагальнені підходи до розкриття облікової політики в розділах приміток «Облікова політика», «Прийняття нових і переглянутих стандартів і тлумачень», «Суттєві судження, оцінки та припущення».

Ключові слова: договір, дохід, облікова політика, визнання, розкриття, фінансові звіти, МСФЗ.

31 січня 2018 року підприємства, які ведуть бухгалтерський облік та складають фінансову звітність за міжнародними стандартами, керуються принципами МСФЗ 15 «Дохід від договорів з клієнтами» [1] для повідомлення користувачам фінансової звітності корисної інформації про природу, оцінку, час та невизначеність доходів і грошових потоків, що виникають внаслідок змісту договору з клієнTом.

Тому такі підприємства повинні були обрати облікову політику до визнання і оцінки доходу за новим стандартом, розробити відповідні примітки щодо доходу для розкриття цієї облікової політики в своїй проміжній та річній фінансовій звітності.

Аналіз останніх публікацій засвідчив, що питання відображен- 
ня у фінансовій звітності доходу за новим МСФЗ 15 докладно розглядалися закордонними науковцями та професіоналами. Аудиторські фірми «Великої четвірки» неодноразово висвітлювали різні аспекти цього стандарту [2; 3; 4; 5], порівнюючи терміни та підходи МСФЗ 15 до визнання і оцінки доходу з його попередниками - МСБО 18 «Дохід» та МСБО 11 «Будівельні контракти». В центрі уваги всіх без винятку публікацій була так звана п'ятикрокова модель визнання доходу.

Всі вітчизняні дослідники (Н. Лоханова, Л. Маценко, С. Дерев'янко та І. Тарасюк, С. Рогозний та О. Карпачова, Н. Салова, О. Храпова, Р. Циган та І. Воробйов, ін.) відмітили важливість визначення облікової політики та ї̈ відмінності від вимог МСБО 18 та МСБО 11, проте не зосереджувалися на їі складових та варіантах застосування за певних умов.

Зважаючи на відсутність таких розробок, було визначено мету даного дослідження - встановити перелік основних елементів облікової політики, їх зміст та розкриття у примітках до фінансових звітів відповідно до вимог МСФЗ 15. Задля досягнення поставленої мети проведено ідентифікацію основних складових облікової політики щодо доходу, запропоновано підходи до їх класифікації, вивчено закордонний та український досвід розкриття облікової політики у примітках до фінансових звітів, запропоновано зміст приміток різного призначення.

Насамперед розглянемо складові облікової політики щодо доходів. Зауважимо, що традиційним $є$ їх поділ на загальні та такі, які безпосередньо відносяться до елемента фінансової звітності, в даному випадку - доходу. Окрім того, різна кількість складових облікової політики надається у розпорядчому документі та розкривається у примітках. Цей аспект взагалі не висвітлений у працях вітчизняних науковців, оскільки традиційно за національними стандартами примітки надавалися лише у числовому вигляді (форма № 5 річної фінансової звітності).

Потрібно зазначити, що пропозиції вітчизняних вчених та практиків знаходяться під впливом позиції регулятора - Міністерства фінансів України, яке вважає, що облікова політика має обиратися тільки в тому випадку, коли стандарти пропонують їі варіанти [6]. Тому для доходів вважалося достатнім вказати порядок оцінки ступеня завершеності операцій з надання послуг та методи визначення ступеня завершеності робіт за будівельним контрактом. Саме такі складові облікової політики виділяють Н.Р. Домбровська, О.А. Лаговська, 
О.М. Савченко, Л.Л. Тягнирядно. Т.М. Чорнявська додає до цих складових розмежування доходів за кожною класифікаційною групою [8].

В.А. Кулик до елементів облікової політики щодо доходів відносить: визначення критеріїв оцінки доходу від надання послуг і виконання робіт на дату складання балансу; вибір методу оцінки ступеня завершеності операцій з надання послуг і робіт за будівельними контрактами, перелік та склад доходів майбутніх періодів [9, С. 196].

Пропозиції автора, викладені у табл. 1, грунтуються на вивченні реальних фінансових звітів підприємств, складених за МСФЗ, праць закордонних дослідників, а також безпосередньо вимог МСФЗ 15. На нашу думку, складові облікової політики доцільно поділити на:

загальні та щодо окремого елемента фінансової звітності;

призначені для регламенту з облікової політики, приміток до річної та проміжної фінансової звітності;

призначені для постійного застосування та для періоду переходу на новий (переглянутий) стандарт.

Таблиця 1

\section{Елементи облікової політики}

щодо доходу та пов'язаних з ним активів і зобов'язань

\begin{tabular}{|c|c|c|c|}
\hline \multirow[t]{2}{*}{ Елементи облікової політики } & \multirow{2}{*}{$\begin{array}{c}\text { Регламент } \\
\text { з облікової } \\
\text { політики }\end{array}$} & \multicolumn{2}{|c|}{ Розкриття у примітках } \\
\hline & & $\begin{array}{c}\text { до річних } \\
\text { фінансових } \\
\text { звітів }\end{array}$ & $\begin{array}{l}\text { до про- } \\
\text { міжних } \\
\text { фінансо- } \\
\text { вих звітів }\end{array}$ \\
\hline 1 & 2 & 3 & 4 \\
\hline \multicolumn{4}{|l|}{ Загальні } \\
\hline $\begin{array}{l}\text { Основа ведення обліку та подання фі- } \\
\text { нансової звітності }\end{array}$ & + & + & + \\
\hline Звітні періоди & + & + & + \\
\hline Суттєвість & + & & \\
\hline Згортання статей фінансових звітів & + & + & + \\
\hline Робочий план рахунків & + & & \\
\hline Період після дати звітності & + & + & + \\
\hline $\begin{array}{l}\text { Інвентаризація активів, зобов'язань та } \\
\text { власного капіталу }\end{array}$ & + & & \\
\hline Процедури закриття рахунків & + & & \\
\hline $\begin{array}{l}\text { Підхід до формування проміжної фінан- } \\
\text { сової звітності за МСБО } 34\end{array}$ & + & & + \\
\hline $\begin{array}{l}\text { Склад та «шаблони» приміток до фінан- } \\
\text { сових звітів }\end{array}$ & + & & \\
\hline Методика та процедури консолідації & + & + & + \\
\hline $\begin{array}{c}\text { Щодо окремих елементів } \\
\text { фінансових звітів (за МСФЗ 15) }\end{array}$ & & & \\
\hline
\end{tabular}


продовження табл. 1

\begin{tabular}{|l|c|c|c|}
\hline 1 & 2 & 3 & 4 \\
\hline Визначення & & & \\
\hline - доходу & + & + & \\
\hline - контрактного активу & + & + & \\
\hline - контрактного зобов'язання & + & + & \\
\hline - дебіторської заборгованості & + & + & \\
\hline Одиниця обліку & & & \\
\hline - за договором & + & + & \\
\hline - за портфелем договорів & + & + & \\
\hline Критерії визнання доходу & + & + & \\
\hline Критерії принципала та агента & + & + & \\
\hline $\begin{array}{l}\text { Критерії та облік угод про продаж з подальшим } \\
\text { викупом }\end{array}$ & + & + & \\
\hline Ознаки класифікації доходу & + & + & + \\
\hline $\begin{array}{l}\text { Перелік та склад доходів за класифікаційними } \\
\text { ознаками }\end{array}$ & + & + & \\
\hline Критерії визнання зобов'язання щодо виконання & & & \\
\hline - які задовольняються з плином часу & + & + & \\
\hline - які задовольняються у певний момент часу & + & + & \\
\hline Оцінка зобов'язань за договором & & & \\
\hline$-\quad$ на підставі ціни окремого продажу & + & & \\
\hline - метод коригування ринкової ціни & + & & \\
\hline$-\quad$ метод оцінки за залишковим принципом & + & & \\
\hline Оцінка доходу - змінна складова & & & \\
\hline - підхід зважених ймовірностей (математичного \\
очікування ціни)
\end{tabular}

Складено автором

Критеріями розподілу елементів облікової політики між тими, які наводяться у регламенті та розкриваються у проміжній та річній фінансовій звітності, є суттєвість. Тому вважаємо, що одиниця обліку - це елемент, який стосується ведення обліку і обов'язків для регламенту з облікової політики, але недоцільний з точки зору розкриття у примітках до фінансових звітів. МСБО 34 «Проміжна фінансова звітність» надає орієнтири яким чином визначити склад приміток до цих звітів.

За новою редакцією Концептуальної основи МСФЗ, одиниця обліку (unit of accounting) - право (а) або обов'язок (i) або групи прав i обов'язків, до яких застосовуються критерії визнання і оцінки [7]. Як 
бачимо, цей підхід орієнтований на такі основні «цеглинки» фінансової звітності як активи (права) та зобов'язання. Але його можливо використати і до доходів, користуючись методом аналогій. Звертаючись до тексту МСФЗ 15, пп. 9-17, 105, визначаємо, що одиницями обліку будуть активи (дебіторська заборгованість, контрактні активи), зобов'язання (контрактні зобов'язання, аванси отримані, доходи майбутніх періодів) та доходи за договором (контрактом) або їх портфелем.

Оскільки визначення $є$ одним з елементів облікової політики і необхідною умовою визнання в обліку та у фінансових звітах, то доцільно виявити усі терміни, які наводяться у тексті стандарту та додатку А до МСФЗ 15. До них відносяться: договір; дебіторська заборгованість; контрактний актив; контрактне зобов'язання, зобов'язання щодо виконання; дохід. Більшість цих термінів $є$ новими, а визначення доходу відрізняється від наданого у МСБО 11 та МСБО 18.

Критерієм визнання доходу за п. 31 МСФЗ $15 €$ втрата контролю продавцем над активом [1]. Нове визначення доходу за Концептуальною основою в редакції 2018 року пояснює, що дохід - це не тільки збільшення активів, але й зменшення зобов'язань, які призводять до збільшення власного капіталу, за винятком тих, які пов'язані з внесками власників власного капіталу [7]. Отже, до визнання доходу веде як припинення визнання активу внаслідок втрати контролю над ним, так і припинення визнання зобов'язання (окрім його погашення).

Тлумачення критеріїв визнання суттєво відрізняється від підходів МСБО 11 та МСБО 18, де розглядалася не втрата контролю, а перехід ризиків та вигод.

Проте чи дохід, отриманий внаслідок виконання договору з клієнтом, повинен визнаватися як дохід від основної діяльності та в повній сумі, залежить від того, ким дане підприємство виступає за цим договором - принципалом чи агентом. Тому в обліковій політиці потрібно навести ознаки агента та принципала, деталізовані в пп. Б34-Б38 Додатку Б до МСФЗ 15, та відповідні облікові підходи.

На визнання доходу також впливає наявність в угоді з клієнтом пунктів щодо подальшого викупу (пп. Б64-Б76 додатку Б до МСФЗ 15). Таким чином, за критеріями, наведеними в стандарті, потрібно вказати коли і якими альтернативними обліковими підходами слід керуватися - МСФЗ 16 «Оренда» або МСФЗ 9 «Фінансові інструменти».

П. 114 МСФЗ 15 визначає ознаки класифікації доходу, які слід розкрити у примітках до фінансових звітів - природа, обсяг, час і невизначеність доходу та грошових потоків [1]. Такими ознаками можуть бути:

тип товару або послуги (наприклад, вид продукції); географічний регіон (наприклад, країна); 
ринок або тип клієнта (наприклад, клієнти - суб'єкти підприємницького та державного секторів);

тип договору (наприклад, договори з фіксованою ціною та змінною складовою);

тривалість договору (короткострокові і довгострокові);

час передачі товарів або послуг (наприклад, дохід визнаний у певний момент часу, і дохід, визнаний з плином часу); та

канали продажу (наприклад, товари, які продаються безпосередньо клієнтам, і товари, які продаються через агентів).

Найбільше нюансів передбачено стандартом та додатком 5 до нього щодо оцінки доходу та зобов'язань за договором. Зважаючи на те, що ці варіанти облікової політики вперше визначені на рівні стандарту, їх теж включено до табл. 1.

Зазначимо, що згідно з можливостями, наданими МСФЗ 15, підприємство повинно було зробити вибір стосовно методу переходу повне ретроспективне застосування або модифіковане ретроспективне застосування для річних періодів, що починаються 1 січня 2018 року або після цієї дати (табл. 2).

Проте вказані в табл. 2 елементи облікової політики, на нашу думку, можуть бути віднесені до тимчасових і потрібні в регламенті та у примітках лише протягом періодів, які пов'язані з першим застосуванням стандарту. Додамо, що аналіз оприлюднених проміжних звітів підприємств свідчить, що вони обрали переважно модифікований варіант переходу на МСФЗ 15.

Склад примітки щодо суттєвих суджень, оцінок та припущень у річній фінансовій звітності визначений пп.123-126 МСФЗ 15 та узагальнений в табл. 3.

Таблиця 2 Варіанти облікової політики підприємства при переході на МСФЗ 15 , та їх вплив на примітки

\begin{tabular}{|c|c|}
\hline \multicolumn{2}{|c|}{ Варіанти облікової політики переходу на МСФЗ 15} \\
\hline $\begin{array}{c}\text { Повний } \\
\text { ретроспективний метод }\end{array}$ & $\begin{array}{l}\text { Модифікований } \\
\text { ретроспективний ме- } \\
\text { тод } \\
\end{array}$ \\
\hline $\begin{array}{l}\text { Застосування ретроспективного методу до кожного по- } \\
\text { переднього звітного періоду, поданого відповідно до } \\
\text { МСБО } 8 \text { «Облік політик, зміни в облікових оцінках та по- } \\
\text { милки» }\end{array}$ & $\begin{array}{l}\text { Застосування ретро- } \\
\text { спективного методу } \\
\text { тільки до договорів, } \\
\text { виконання яких не за- } \\
\text { вершено на дату пере- } \\
\text { ходу на МСФ3 } 15\end{array}$ \\
\hline
\end{tabular}


продовження табл. 2

\begin{tabular}{|c|c|c|c|}
\hline \multicolumn{4}{|c|}{ Можливі практичні прийоми } \\
\hline $\begin{array}{l}\text { для заверше- } \\
\text { них договорів } \\
\text { суб'єктові го- } \\
\text { сподарюван- } \\
\text { ня не потрібно } \\
\text { перерахову- } \\
\text { вати догово- } \\
\text { ри, які почи- } \\
\text { наються і за- } \\
\text { кінчуються в } \\
\text { одному й тому } \\
\text { ж звітному } \\
\text { періоді }\end{array}$ & $\begin{array}{l}\text { для завершених } \\
\text { договорів, які пе- } \\
\text { редбачають } \\
\text { змінну компен- } \\
\text { сацію, суб'єкт го- } \\
\text { сподарювання } \\
\text { може використа- } \\
\text { ти ціну операції } \\
\text { на дату завер- } \\
\text { шення договору і } \\
\text { не оцінювати ве- } \\
\text { личини змінної } \\
\text { компенсації у по- } \\
\text { рівняльних звіт- } \\
\text { них періодах }\end{array}$ & $\begin{array}{l}\text { для всіх звітних пері- } \\
\text { одів, поданих до дати } \\
\text { первісного застосу- } \\
\text { вання, суб'єктові гос- } \\
\text { подарювання не пот- } \\
\text { рібно розкривати суму } \\
\text { операції, розподілену } \\
\text { на решту зобов'язань } \\
\text { щодо виконання, а та- } \\
\text { кож пояснення щодо } \\
\text { того, коли суб'єкт гос- } \\
\text { подарювання очікує } \\
\text { визнати таку суму як } \\
\text { дохід }\end{array}$ & 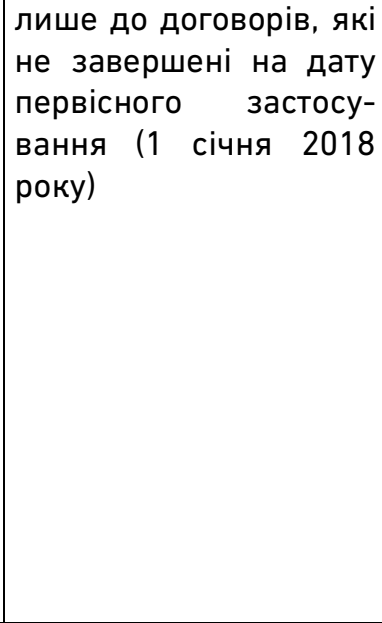 \\
\hline \multicolumn{4}{|c|}{ Вплив на примітки до фінансових звітів } \\
\hline \multicolumn{3}{|c|}{$\begin{array}{l}\text { практичні прийоми, які були використані; та } \\
\text { наскільки це практично можливо, кількісну оцінку попе- } \\
\text { редньо визначеного ефекту застосування кожного тако- } \\
\text { го практичного прийому }\end{array}$} & $\begin{array}{l}\text { сума, на яку змінюєть- } \\
\text { ся кожний рядок фі- } \\
\text { нансового звіту у по- } \\
\text { точному звітному пері- } \\
\text { оді внаслідок застосу- } \\
\text { вання МСФЗ } 15 \text { порів- } \\
\text { няно з МСБО 11, МСБО } \\
18 \text { та відповідними } \\
\text { Тлумаченнями, які бу- } \\
\text { ли чинними до цієї } \\
\text { зміни; та } \\
\text { пояснення причин сут- } \\
\text { тєвих змін }\end{array}$ \\
\hline
\end{tabular}

Складено автором

Таблиця 3

Суттєві судження при застосуванні МСФЗ 15

Склад примітки «Істотні облікові судження, оціночні значення і припущення» стосовно доходу та пов'язаних з ним статей

час задоволення зобов'я- ціна операції та суми, що розподіляються на зобов'язання щодо виконання зання щодо виконання

методи, використані го, чому за- ціни опера- чи є оцінка ціни опе- язань щодо для ви- стосовані ме- ції змінної рації на повернення, знання дотоди забезкомпенсації конкретні відшкодування ходу печують достовірне відображення пеобмеженою частини та інших подідоговору бних зобов'яредачі товарів або послуг зань

Складено автором за [1] 
Для підприємств, які вже використовували МСФЗ у попередні звітні періоди, примітки щодо впливу нового стандарту повинні бути надані ще до фінансових звітів за I квартал 2018 року. Зокрема, назва та текст примітки могли мати такий вигляд.

Нові стандарти, тлумачення та поправки до чинних

стандартів, вперше застосовані підприємством (групою)

Облікова політика, прийнята при складанні проміжної (консолідованої - у разі групи) фінансової звітності, відповідає політиці, яку застосовували при складанні річної (консолідованої - у разі групи) фінансової звітності за рік, що закінчився 31 грудня 2017 р. за винятком прийнятих нових стандартів, що набрали чинності $з 1$ січня 2018 року. Підприємство (група) достроково не застосовувало будь-які інші стандарти, тлумачення або поправки, які були випущені Радою з МСФЗ, але ще не є чинними.

Підприємство (група) вперше застосовує МСФЗ (IFRS) 15 «Дохід від договорів з клієнтами» і МСФЗ (IFRS) 9 «Фінансові інструменти».

Далі у примітці слід розкрити вплив нового стандарту на визнання доходу та інших показників фінансової звітності. У табл. 4 наведено перелік деяких показників, яких це торкнеться, та запропоновані приклади розкриття.

Таблиця 4

Приклади варіантів розкриття впливу першого застосування МСФЗ 15 на окремі показники фінансових звітів

\begin{tabular}{|c|c|c|}
\hline Назва статті & Звіт & Можливий вплив \\
\hline $\begin{array}{l}\text { Чистий } \\
\text { дохід - } \\
\text { продаж продук- } \\
\text { ції }\end{array}$ & $\begin{array}{l}\text { Звіт про прибут- } \\
\text { ки/ збитки та } \\
\text { інший сукупний } \\
\text { дохід }\end{array}$ & $\begin{array}{l}\text { Застосування МСФЗ (IFRS) } 15 \text { до договорів з } \\
\text { клієнтами, за якими передбачається, що } \\
\text { єдиним зобов'язанням до виконання буде } \\
\text { продаж готової продукції, не вплинуло на } \\
\text { дохід і прибуток або збиток. Визнання дохо- } \\
\text { ду відбувається у момент часу, коли конт- } \\
\text { роль над активом передається покупцеві. }\end{array}$ \\
\hline $\begin{array}{l}\text { Чистий дохід - } \\
\text { змінна винаго- } \\
\text { рода }\end{array}$ & $\begin{array}{l}\text { Звіт про прибут- } \\
\text { ки/ збитки та } \\
\text { інший сукупний } \\
\text { дохід }\end{array}$ & $\begin{array}{l}\text { Підприємство не має значних угод з надан- } \\
\text { ням торгових знижок, тому обмеження } \\
\text { МСФЗ } 15 \text { щодо змінного відшкодування не } \\
\text { спричинили істотного впливу на фінансові } \\
\text { результати. }\end{array}$ \\
\hline $\begin{array}{l}\text { Чистий дохід - } \\
\text { виконання ро- } \\
\text { біт, надання по- } \\
\text { слуг }\end{array}$ & $\begin{array}{l}\text { Звіт про прибут- } \\
\text { ки/ збитки та } \\
\text { інший сукупний } \\
\text { дохід }\end{array}$ & $\begin{array}{l}\text { Дохід від виконання робіт та надання послуг } \\
\text { підприємством визнається з плином часу, } \\
\text { враховуючи, покупець одночасно отримує та } \\
\text { споживає вигоди, які надаються. Застосу- } \\
\text { вання МСФЗ } 15 \text { не вплинуло на дохід, собі- } \\
\text { вартість продажу та фінансові результати } \\
\text { підприємства }\end{array}$ \\
\hline
\end{tabular}


продовження табл. 4

\begin{tabular}{|c|c|c|}
\hline $\begin{array}{l}\text { Дебіторська за- } \\
\text { боргованість за } \\
\text { товари, роботи, } \\
\text { послуги }\end{array}$ & $\begin{array}{l}\text { Звіт про фінан- } \\
\text { совий стан }\end{array}$ & $\begin{array}{l}\text { Коригування в результаті застосування нових } \\
\text { правил знецінення згідно з МСФЗ } 9 \text { істотно не } \\
\text { вплинуло на фінансовий стан або фінансові } \\
\text { показники діяльності підприємства, тому по- } \\
\text { рівняльні дані і вхідні залишки власного капі- } \\
\text { талу на } 1 \text { січня } 2018 \text { р. не були переглянуті. } \\
\text { Підприємство застосувало спрощену модель } \\
\text { розрахунку очікуваного кредитного збитку } \\
\text { для дебіторської заборгованості відповідно } \\
\text { до вимог МСФЗ 9. }\end{array}$ \\
\hline $\begin{array}{l}\text { Зобов'язання за } \\
\text { контрактом }\end{array}$ & $\begin{array}{l}\text { Звіт про фінан- } \\
\text { совий стан }\end{array}$ & $\begin{array}{l}\text { МСФЗ } 15 \text { також вимагає, щоб забезпечення } \\
\text { для повернення під час продажу були рекла- } \\
\text { сифіковані. Раніше ці забезпечення підляга- } \\
\text { ли виключенню з дебіторської заборгованості } \\
\text { та з } 1 \text { січня } 2018 \text { року вони відображені од- } \\
\text { ночасно як окремі зобов'язання щодо повер- } \\
\text { нення у складі торговельних зобов'язань та } \\
\text { запаси, які підлягають поверненню, у складі } \\
\text { запасів. Вплив переходу збільшив торговель- } \\
\text { ну дебіторську заборгованість на ... тис. грн., } \\
\text { зобов'язання та запаси на ... тис. грн. }\end{array}$ \\
\hline $\begin{array}{l}\text { Гарантійні зо- } \\
\text { бов'язання }\end{array}$ & $\begin{array}{l}\text { Звіт про фінан- } \\
\text { совий стан }\end{array}$ & $\begin{array}{l}\text { Підприємство надає гарантію на звичайний } \\
\text { ремонт реалізованої продукції та відображає } \\
\text { ї̈ за МСБО } 37 \text { «Забезпечення, умовні зо- } \\
\text { бов'язання та умовні активи» }\end{array}$ \\
\hline
\end{tabular}

Складено автором

Слід зазначити, що Рада з фінансової звітності Великобританії [10] визначила подібні важливі напрямки розкриття у фінансових звітах за 2018 рік інформації про перше застосування МСФЗ 15:

пояснення змін в обліковій політиці та інформація про коригування у зв'язку із переходом на МСФЗ 15;

опис облікової політики, включаючи причини змін та суджень, зроблені керівництвом при переході на нову політику;

інформація про виконання зобов'язань за контрактом із покупцями, в т.ч. судження, зроблені при визначенні цих зобов'язань і термінах їх виконання (тобто при передачі контролю клієнту);

вплив на баланс, включаючи розкриття інформації щодо облікової політики для нових статей, таких як контрактні активи та зобов'язання за контрактом.

Висновки. Перше застосування МСФЗ 15 «Дохід від договорів 3 клієнтами» вимагає від підприємств та їх об'єднань ґрунтовного аналізу облікової політики щодо доходу, розкриття суті та впливу змін, які відбулися (або їх відсутності) на показники фінансової звітності, розробки нового «шаблону» таблиць за складниками доходу відпо- 
відно до обраних ознак класифікації, а також договірних активів і зобов'язань тощо. Огляд оприлюднених проміжних фінансових звітів надав можливість зробити висновок, що українські підприємства недостатньо розкрили вплив переходу на МСФЗ 15 . Подальші дослідження будуть присвячені аналізу адекватності розкриття облікової політики стосовно доходу у річній фінансовій звітності за перший рік запровадження вимог МСФЗ 15 українськими підприємствами та обгрунтуванню належної облікової політики як одного з чинників підвищення достовірності, прозорості й корисності фінансової звітності.

1. МСФЗ 15 «Дохід від договорів 3 клієнтами» URL: https://www.minfin.gov.ua/ uploads/redactor/files/IFRS\%2015_ukr_2016.pdf (дата звернення 01.07.2018). 2. Применение МСФО. Подробное рассмотрение нового стандарта по признанию выручки. Эрнст энд Янг, 2016. 235 с. URL: https://www.ey.com/Publication/ vwLUAssets/ey-applying-ifrs-revenueifrs-15-rus/\$FILE/ey-applying-ifrs-revenue-ifrs-15-rus.pdf (дата звернення: 15.01.2019). 3. Revenue from contracts with customers. A guide to IFRS 15. March 2018.2 Deloitte. URL: https://www.iasplus.com/en/publications/global/guides/a-guide-to-ifrs-

15/file (дата звернення 01.07.2018). 4. Выручка по договорам с покупателями. КРМГ. Июнь 2016. URL: https://home.kpmg/ru/ru/home/insights/ 2017/02/ first-impression-revenue-2014.html (дата звернення 01.07.2018). 5. IFRS 15 - Revenue from contracts with customers. PWC, 2018. URL: https://inform.pwc.com/inform2/s/Revenue_from_contracts_with_customers _IFRS_15/informContent/1449262206139404 (дата звернення 01.10.18). 6. Про затвердження методичних рекомендацій щодо облікової політики підприємства та внесення змін до деяких наказів Міністерства фінансів України : Наказ Мінфіну України від 27 червня 2013 р. N 635. URL: www. Financeforyou.com.ua/wp-content/uploads/2015/11/ minfinna635-1.dос (дата звернення 01.07.2018). 7. Conceptual Framework for Financial Reporting. IASB, 2018. URL: https://www.ifrs.org/-/media/project/conceptualframework/fact-sheet-project-summary-and-feedback-statement/conceptualframework-project-summary.pdf (дата звернення 01.07.2018) 8. Кулик В. А. Облікова політика підприємства: набутий досвід та перспективи розвитку : монографія. Полтава : РВВ ПУЕТ, 2014. 373 с. 9. Чорнявська Т. М. Облікова політика підприємства як фактор управління доходами і фінансовими результатами діяльності. Облік і фінанси АПК : бухгалтерський портал. URL: http://magazine.faaf.org.ua/oblikova-politika-pidpriemstva-yak-faktorupravlinnya-dohodami-i-finansovimi-rezultatami-diyalnosti.html (дата звернення 01.07.2018) 10. IFRS 15. Thematic Review: Review of Interim Disclosures in the First Year of Application. November 2018. FRC. URL: https://www.frc.org.uk/getattachment/1d8558b8-73bf-4a13-bec7-

9c350bfcc1 ba/ IFRS-15-thematic-report-2-November-2018-v2.pdf (дата звернення 01.09.2018). 


\section{REFERENCES:}

1. MSFZ 15 «Dokhid vid dohovoriv $z$ kliientamy» URL: https://www.minfin.gov.ua/ uploads/redactor/files/IFRS\%2015_ukr_2016.pdf (data zvernennia 01.07.2018). 2. Primenenie MSFO. Podrobnoe rassmotrenie novoho standarta po priznaniiu vyruchki. Ernst end Yanh, 2016. 235 s. URL: https://www.ey.com/Publication/ vwLUAssets/ey-applying-ifrs-revenue-ifrs15-rus/\$FILE/ey-applying-ifrs-revenue-ifrs-15-rus.pdf (data zvernennia: 15.01.2019). 3. Revenue from contracts with customers. A guide to IFRS 15. March $2018 . \quad$ Deloitte. URL: https://www.iasplus.com/en/publications/global/guides/a-guide-to-ifrs15/file (data zvernennia 01.07.2018). 4. Vyruchka po dohovoram s pokupateliami. KRMH. liun 2016. URL: https://home.kpmg/ru/ru/home/insights/ 2017/02/ first-impression-revenue-2014.html (data zvernennia 01.07.2018). 5. IFRS 15 - Revenue from contracts with customers. PWC, 2018. URL: https://inform.pwc.com/inform2/s/Revenue_from_contracts_with_customers _IFRS_15/informContent/1449262206139404 (data zvernennia 01.10.18). 6. Pro zatverdzhennia metodychnykh rekomendatsii shchodo oblikovoi polityky pidpryiemstva ta vnesennia zmin do deiakykh nakaziv Ministerstva finansiv Ukrainy : Nakaz Minfinu Ukrainy vid 27 chervnia 2013 r. N 635. URL: www. Financeforyou.com.ua/wp-content/uploads/2015/11/ minfinna635-1.doc (data zvernennia 01.07.2018). 7. Conceptual Framework for Financial Reporting. IASB, 2018. URL: https://www.ifrs.org/-/media/project/conceptualframework/fact-sheet-project-summary-and-feedback-statement/conceptualframework-project-summary.pdf (data zvernennia 01.07.2018). 8. Kulyk V. A. Oblikova polityka pidpryiemstva: nabutyi dosvid ta perspektyvy rozvytku : monohrafiia. Poltava : RVV PUET, 2014. 373 s. 9. Chorniavska T. M. Oblikova polityka pidpryiemstva yak faktor upravlinnia dokhodamy i finansovymy rezultatamy diialnosti. Oblik $i$ finansy APK : bukhhalterskyi portal. URL: http://magazine.faaf.org.ua/oblikova-politika-pidpriemstva-yak-faktorupravlinnya-dohodami-i-finansovimi-rezultatami-diyalnosti.html (data zvernennia 01.07.2018). 10. IFRS 15. Thematic Review: Review of Interim Disclosures in the First Year of Application. November 2018. FRC. URL: https://www.frc.org.uk/getattachment/1d8558b8-73bf-4a13-bec7-

9c350bfcc1ba/ IFRS-15-thematic-report-2-November-2018-v2.pdf (data zvernennia 01.09.2018).

Рецензент: д.е.н., професор Савіна Н. Б. (НУВГП) 
Zubilevych S. Y., Candidate of Economics (Ph.D.), Professor (National University of Water and Environmental Engineering, Rivne)

\section{FORMATION AND DISCLOSURE OF ACCOUNTING POLICY UNDER IFRS 15 "INCOME FROM CONTRACTS WITH CUSTOMERS"}

The basic elements of the accounting policy concerning the income are determinate. These elements are include the basis of the accounting and reporting, the materiality, offsetting, the work chart of accounts, accounting unit, recognition criteria's, classification, evaluation, disclosure, and others. It is suggested to distinguish between the following components of the accounting policy: for the purposes of drawing up the rules of the accounting policy and notes to the financial statements; general and those that relate directly to a particular item of financial statements; permanent and temporary, appointed for the transition to new (revised) standards. A comparison between requirements in IAS 18 Revenue, IAS 11 Construction Contracts and IFRS 15 Revenue from Customer Contracts regarding terminology and a list of key elements of accounting policies and estimates has been proposed. The approach to the formation of an accounting policy on revenue based on IFRS 15 requirements is developed. The analysis of the matching of the recognition, measurement and disclosures of revenue and related balance sheet items in the interim financial statements for the year ended by 31 December 2018 with the requirements of IFRS 15 is carried out in accordance. The approaches to disclosure the accounting policy in the notes section "Accounting policy", "The adoption of new and revised standards and interpretations", "Essential considerations, estimates and assumptions" are generalized.

Keywords: contract, revenue, accounting policy, recognition, disclosure, financial statements, IFRS.

Зубилевич С. Я., к.э.н., профессор (Национальный университет водного хозяйства и природопользования, г. Ровно)

ФОРМИРОВАНИЕ И РАСКРЫТИЕ УЧЕТНОЙ ПОЛИТИКИ СОГЛАСНО МСФО 15 «ДОХОД ОТ ДОГОВОРОВ С КЛИЕНТАМИ»

Определены основные элементы учетной политики в отношении дохода, к которым отнесены основа ведения учета и представления отчетности, существенность, сворачивание, рабочий план сче- 
тов, объект учета, определения, признание, классификация, оценка и другие. Предложено различать такие составляющие учетной политики: для нужд составления регламента по учетной политике и примечаний к финансовой отчетности; общие и те, которые непосредственно касаются отдельного элемента финансовой отчетности; постоянные и временные, связанные с переходом на новый (пересмотренный) стандарт. Проведено сравнение требований МСБУ 18 «Доход», МСБУ 11 «Строительные контракты» и МСФО 15 «Доход от договоров с клиентами» относительно терминологии и перечня основных элементов учетной политики и оценки. Предложен подход к формированию регламента об учетной политике в части дохода с учетом требований МСФО 15. Осуществлен анализ опубликованных финансовых отчетов предприятий относительно признания, оценки и раскрытия дохода в промежуточной финансовой отчетности за 2018 в соответствии с требованиями МСФО 15. Обобщены подходы к раскрытию учетной политики в разделах примечаний «Учетная политика», «Принятие новых и пересмотренных стандартов и интерпретаций», «Существенные суждения, оценки и допущения».

Ключевые слова: договор, доход, учетная политика, признание, раскрытие, финансовые отчеты, МСФО. 